\title{
T-cellular immune reactions (in macrophage inhibition factor assay) against Mycobacterium paratuberculosis, Mycobacterium kansasii, Mycobacterium tuberculosis, Mycobacterium avium in patients with chronic inflammatory bowel disease
}

\author{
C A Seldenrijk, H A Drexhage, S G M Meuwissen, C J L M Meijer
}

\begin{abstract}
A mycobacterial aetiology has been suggested for Crohn's disease. A slow growing mycobacterium, biochemically and genetically identical to $M$ paratuberculosis, the causative agent of enteritis in ruminants (Johne's disease), has been isolated from gut specimens of patients affected by Crohn's disease. If $M$ paratuberculosis or other mycobacteria play a role in the pathogenesis of Crohn's disease, then patients may have been sensitised to these mycobacteria or show an anergy immune reaction. We therefore investigated the $T$-cell mediated immune response to sonicates of $M$ paratuberculosis, $M$ kansasii, $M$ avium, and $M$ tuberculosis in 35 patients with Crohn's disease, 28 with ulcerative colitis, and 25 controls using a macrophage inhibition factor assay on peripheral blood lymphocytes. Two types of reaction patterns were identified - that is, 'responders' (subjects with a macrophage inhibition factor assay in which a dose response relation was present and a percentage of inhibition exceeding $20 \%$ ), and 'nonresponders'. There was no significant difference in the prevalence of responders $(59 \%$ $80 \%)$ and non-responders $(20 \%-41 \%)$ to these mycobacteria between the group of Crohn's disease, ulcerative colitis, and control group. We found also that a large proportion of controls showed $\mathbf{T}$-cell immunisation to the mycobacteria which supports the contention that the antigens are practically commensal. Our results do not support the proposed involvement of mycobacteria in the pathogenesis of Crohn's disease.
\end{abstract}

Free University Hospital of Amsterdam, The Netherlands,

Department of Patholory C A Seldenrijk

H A Drexhage

C J LM Meijer

Department of Gastroenterology S G M Meuwissen

Correspondence to: C A Seldenrijk, MD, Department of Pathology, Free University Hospital of Amsterdam, De Boelelaan 1117, 1080 HV Amsterdam, The Netherlands.

Accepted for publication 10 August 1989
Since Dalziel's initial description of Crohn's disease in $1913^{\prime}$ many microbial aetiologies such as the involvement of Yersinia enterocolitica, pseudomonas-like organisms, Escherichia coli, Streptococcus faecalis L-forms, chlamydia, and mycoplasma ${ }^{2-4}$ have been postulated for the disease. Currently there is a renewed interest for a putative role of mycobacteria in Crohn's disease. ${ }^{5-10}$

In 1972, Patterson and Allen put emphasis on the similarities between Crohn's disease and Johne's disease of cattle." Johne's disease is known to be caused by Mycobacterium paratuberculosis. ${ }^{112}$ This wasting disease is characterised, as Crohn's disease, by a transmural chronic granulomatous inflammatory reaction, principally of the terminal ileum but also of the caecum, colon, and occasionally of other organs and regions of the gut. ${ }^{13}$

Evidence of a possible aetiological link between these diseases came only recently, when Chiodini et $a l^{561415}$ isolated a mycobacterium species from surgical gut specimens of four patients with Crohn's disease. The mycobacterium isolated from patients with Crohn's disease was biochemically, and genetically similar to $M$ paratuberculosis of Johne's disease. ${ }^{16}$ The investigators hypothesised that the slow growing mycobacterium played an aetiological role in at least some cases of Crohn's disease.

Since this initial report, isolation studies of mycobacteria have given controversial data. Graham and collaborators isolated several mycobacterial species from colon tissues of Crohn's disease patients, but similar organisms could regularly be isolated from ulcerative colitis patients, patients with colon diseases other than chronic inflammatory bowel disease (nonchronic inflammatory bowel disease control group), and even healthy individuals. ${ }^{17}$ These authors concluded that a direct association between the presence of mycobacteria in the gut and Crohn's disease or ulcerative colitis could not be established. They suggested that the isolation of mycobacteria from Crohn's disease, ulcerative colitis, non-chronic inflammatory bowel disease, and healthy gut tissues earlier favoured the hypothesis that chronic inflammatory bowel disease might be the result of an abnormal immune response to these commensally occurring mycobacteria.

If $M$ paratuberculosis does play a role in the pathogenesis of Crohn's disease, it is conceivable that Crohn's disease patients will either have a defective response to this mycobacterium (if the mycobacterium is commensal) or they will show an enhanced immune response to the bacterium while healthy controls will not (if the mycobacterium is a direct pathogen, or if the host is hypersensitive to the mycobacterium). Mycobacteria in general is known to give rise to $\mathrm{T}$-cell mediated immune reactions. The presence of granulomas in gut specimens of patients with Crohn's disease also indicate that $T$ cells might be involved in its pathogenesis.

There are a few well accepted parameters to assess $\mathrm{T}$-cell mediated immunity to mycobacterial antigens, such as the delayed type hypersensitivity skin test (for instance the tuberculin test), the lymphocyte transformation 
test and the macrophage inhibition factor assay. ${ }^{18}$

Skin tests do provide valuable information, but are inconvenient for patients, and directly influence the immunological status of the patient by inducing a further $\mathrm{T}$-cellular sensitisation. In our experience the lymphocyte transformation test responses to microbial antigens show considerable fluctuations from positive to negative and vice versa in healthy individuals as well as in patients ${ }^{18}$; other authors have reported similar experiences. ${ }^{19}$ In contrast with these difficulties with the lymphocyte transformation test, we found a good correlation between the outcome of macrophage inhibition factor assays and skin tests. ${ }^{18}$ We therefore prefer macrophage inhibition factor assay to assess $\mathrm{T}$-cell reactivity against microbial antigens.

There are only a few reports in which the Tcellular immunity of Crohn's disease patients against mycobacteria have been investigated. ${ }^{72021}$ In the present study the T-cell mediated immunity of chronic inflammatory bowel disease patients against several mycobacterial species - that is, $M$ paratuberculosis, $M$ kansasii, $M$ avium, and $M$ tuberculosis was investigated using sonicates of these microorganism in the macrophage inhibition factor assay.

\section{Methods}

\section{PATIENTS}

Thirty five patients with Crohn's disease were included in this investigation (mean age 35 years, range $22-68,22$ women and 13 men). Twenty six were on specific medication: six on oral prednisone, two were treated with prednisone containing enemas, eight on salazopyrine, seven on 5-aminosalicylic-acid, and three patients had a combination of azathioprine and prednisone.

Twenty eight patients with ulcerative colitis were included in this investigation (mean age 36 years, range $21-77,12$ women and 16 men). Twenty four patients were on specific medication: 13 on salazopyrine (one in combination with prednisone containing enemas, and one with azathioprine), 10 on oral prednisone (four in combination with 5-aminosalicylic-acid; one in combination with prednisone containing enemas and one with salazopyrine), one on 5 aminosalicylic-acid, and two on a triple therapy that is, one on salazopyrine, oral prednisone, and prednisone containing enemas, one on salazopyrine, oral prednisone and azathioprine.

The diagnosis of Crohn's disease or ulcerative colitis was based on the characteristic clinical history, endoscopy findings and confirmed with microscopical criteria of biopsy material. ${ }^{22}$

NON-CHRONIC INFLAMMATORY BOWEL DISEASE CONTROL PATIENTS AND

HEALTHY INDIVIDUALS

This group consisted of 25 cases (mean age 45 years, range $21-86$, seven women and $17 \cdot$ men) including 16 healthy volunteers and nine patients with gut diseases other than chronic inflammatory bowel disease such as diverticular disease (six), colon polyps (one), or adenocarci- noma of the colon (two). These patients did not receive any immunosuppressive medication.

\section{COLLECTION OF BLOOD MONONUCLEAR}

CELLS

Heparinised blood was collected by venepuncture and Ficoll-Isopaque density gradient centrifugation was used to isolate mononuclear cells. The cells were washed twice with physiologic salt solution and frozen $\left(-20^{\circ} \mathrm{C}\right)$ until further use.

MYCOBACTERIAL ANTIGENS USED IN THE MACROPHAGE INHIBITION FACTOR ASSAY Freeze dried sonicates of $M$ paratuberculosis, $M$ kansasii, $M$ avium, and $M$ tuberculosis were used as antigens. The sonicate of $M$ paratuberculosis, NADC strain M18, originally isolated from Johne's disease was kindly provided by Dr J Haagsma of the Central Veterinary Institute, Lelystad, the Netherlands, and prepared according to Merkal et al. ${ }^{23}{ }^{24}$ The other mycobacterial sonicates were gifts from $\mathrm{Dr}$ A $\mathrm{H} \mathrm{J}$ Kolk of the NH Swellengrebel Laboratory of Tropical Hygiene, Royal Tropical Institute, Amsterdam, the Netherlands, and prepared as previously described..$^{25}$ For this purpose the mycobacteria had been grown on Sauton medium, were suspended in $0.01 \mathrm{M}$ phosphate buffered saline, $\mathrm{pH}$ $7 \cdot 2$ and sonicated at $90 \mathrm{~W}$ on ice for $60 \mathrm{~min}$ at setting of $50 \%$ duty cycle in a Branson sonicator B15 (Branson Sonic Power Co, Danbury, Connecticut, USA). The sonicates were stored at $-70^{\circ} \mathrm{C}$, until further use. Sonicates were dissolved in HEPES-buffered RPMI 1640 culture fluid for use in the in vitro macrophage inhibition factor assay.

As positive macrophage inhibition factor production stimulus the mitogen concanavalin $A$, at a concentration of $5 \mu \mathrm{g} / \mathrm{ml}$ HEPES buffered RPMI 1640 (Con A, Sigma, St Louis, USA) was used. Ovalbumin was used as a negative control antigen. Healthy controls were not expected to be sensitised to this antigen.

\section{MACROPHAGE MIGRATION INHIBITION} FACTOR TEST

Macrophage inhibition factor production was estimated with an indirect microdroplet agarose assay. Throughout the test the medium used was HEPES-buffered RPMI 1640 containing glutamine and supplemented with penicillin, Streptomycine and $10 \%$ fetal calf serum.

Mononuclear cells $\left(2.5 \times 10^{6}\right)$ were cultured in the wells of round bottom microtitreplates. Antigens were added to obtain a final concentration of $0.5,2.5,10$, and $44 \mu \mathrm{g} / \mathrm{ml}$ for mycobacterial antigens. Supernatants were also prepared using con $\mathrm{A}$ in a final concentration of $5 \mu \mathrm{g} / \mathrm{ml}$. Supernatants were collected (10 min, $\times 2000 \mathrm{~g})$ after three days of culture $\left(37^{\circ} \mathrm{C}, 5 \%\right.$ $\mathrm{CO}_{2}$ in air) and stored at $-20^{\circ} \mathrm{C}$ until testing for macrophage inhibition factor activity.

The agarose microdroplet assay was performed in principle according to Thurman et $a l^{26}$ using the monocytoid U937 cell-line as indicator cells. ${ }^{27}$ The cell line was maintained and propagated in the above culture fluid at $37^{\circ} \mathrm{C}$ in $5 \%$ 
$\mathrm{CO}_{2}$ in air. Cells were harvested in the logarithmic growth phase, counted, washed (10 $\mathrm{min}, \times 200 \mathrm{~g}$ ), resuspended in a small volume of medium and transferred to a $1.5 \mathrm{ml}$ conical tube, and reconcentrated by centrifugation $(10 \mathrm{~min}$, $\times 200 \mathrm{~g}$ ). The pellet was resuspended at room temperature $\left(2 \times 10^{7}\right.$ cells $\left./ \mathrm{ml}\right)$ in a $0 \cdot 2 \%$ agarose solution. This solution was prepared by dissolving $20 \mathrm{mg}$ sea plaque agarose of low gelling temperature (Marine Colloids, Rockland, USA) in $1 \mathrm{ml}$ phosphate buffered saline $(\mathrm{pH} 7 \cdot 4)$ at $120^{\circ} \mathrm{C}$ and diluting it ten times with medium, before adding the cells.

From this cell suspension, $1 \mu$ droplets were centrally placed in wells of flat bottom microtitreplates (Nunc, Denmark) using a Hamilton Repeating Dispenser with a $0.05 \mathrm{ml}$ gas-tight syringe (Hamilton, Reno, USA). The droplets were left to solidify at $4^{\circ} \mathrm{C}$ for $10-20$ minutes and carefully overlaid with $0.1 \mathrm{ml}$ of thawed supernatants diluted 1:1 with fresh medium. All tests were carried out in three-fold. After incubation of the covered plates for $21 \mathrm{~h}$ at $37^{\circ} \mathrm{C}$, and $5 \%$ $\mathrm{CO}_{2}$ in air, migration areas (cell migration area minus area of the agarose droplet) were computed using a projection microscope and a graphic tablet connected with a Mop Videoplan.

Macrophage inhibition factor production was expressed as \% of migration inhibition:

$$
\begin{gathered}
\text { macrophage inhibition }=100-100 \times \\
\text { mean migration area in antigen-stimulated cultures } \\
\text { mean migration area in medium }
\end{gathered}
$$

\section{Results}

The U937 indicator cell system provided reproducible results; the intra-experimental variation in the migration of the indicator cells in the agarose droplets in the absence of any macrophage inhibition factor or other stimulus was less than $10 \%$.

Ovalbumin was used as antigen to test the migration of the U937 indicator system in the presence of a negative lymphocyte culture supernatant. In addition 10 patients with Crohn's disease, 10 patients with ulcerative colitis, and nine non-chronic inflammatory bowel disease controls were tested at four concentrations of the antigen - that is, $0.5,2.5,10,44 \mu \mathrm{g} / \mathrm{ml}$, in the macrophage inhibition factor assay.

Results are shown in Figure 1. Dose response curves were not recorded in any of the groups tested, and inhibition (or stimulation) values never exceeded a $20 \%$ limit of migration found with culture fluid alone. There was no difference in the macrophage inhibition factor assay outcomes between healthy controls, non-chronic inflammatory bowel disease patients and patients with Crohn's disease or ulcerative colitis. The data can be taken to indicate that none of the patients or healthy individuals had $T$-cell reactivity towards ovalbumin. On the bases of these data we considered an inhibition of migration of $>20 \%$ as to represent the presence of macrophage inhibition factor in the indicator system.

Using this criterium $74 \%$ of the patients with Crohn's disease and $79 \%$ of the patients with ulcerative colitis showed a positive lymphokine
TABLE Prevalence of responders and non-responders in the

\begin{tabular}{|c|c|c|c|c|c|c|}
\hline \multirow[b]{2}{*}{ Antigen } & \multicolumn{2}{|c|}{ Controls } & \multicolumn{2}{|c|}{ Crohn's disease } & \multicolumn{2}{|c|}{ Ulcerative colitis } \\
\hline & $\operatorname{Resp}$ & Non-resp & $\operatorname{Resp}$ & Non-resp & $\operatorname{Resp}$ & Non-resp \\
\hline Con $\mathrm{A}$ & $\begin{array}{l}16 / 25 \\
(64 \%)\end{array}$ & $\begin{array}{c}9 / 25 \\
(36 \%)\end{array}$ & $\begin{array}{l}26 / 35 \\
(74 \%)\end{array}$ & $\begin{array}{c}9 / 35 \\
(26 \%)\end{array}$ & $\begin{array}{l}22 / 28 \\
(79 \%)\end{array}$ & $\begin{array}{c}6 / 28 \\
(21 \%)\end{array}$ \\
\hline MP & $\begin{array}{l}20 / 25 \\
(80 \%)\end{array}$ & $\begin{array}{c}5 / 25 \\
(20 \%)\end{array}$ & $\begin{array}{l}27 / 35 \\
(77 \%)\end{array}$ & $\begin{array}{c}8 / 35 \\
(23 \%)\end{array}$ & $\begin{array}{l}22 / 28 \\
(79 \%)\end{array}$ & $\begin{array}{l}6 / 28 \\
(21 \%)\end{array}$ \\
\hline MK & $\begin{array}{l}13 / 23 \\
(64 \%)\end{array}$ & $\begin{array}{l}10 / 23 \\
(46 \%)\end{array}$ & $\begin{array}{l}16 / 26 \\
(62 \%)\end{array}$ & $\begin{array}{l}10 / 26 \\
(38 \%)\end{array}$ & $\begin{array}{l}12 / 21 \\
(57 \%)\end{array}$ & $\begin{array}{c}9 / 21 \\
(43 \%)\end{array}$ \\
\hline MA & $\begin{array}{l}13 / 20 \\
(65 \%)\end{array}$ & $\begin{array}{c}7 / 20 \\
(35 \%)\end{array}$ & $\begin{array}{l}10 / 23 \\
(43 \%)\end{array}$ & $\begin{array}{l}13 / 23 \\
(57 \%)\end{array}$ & $\begin{array}{r}9 / 16 \\
(56 \%)\end{array}$ & $\begin{array}{c}7 / 16 \\
(44 \%)\end{array}$ \\
\hline MT & $\begin{array}{l}10 / 17 \\
(59 \%)\end{array}$ & $\begin{array}{c}7 / 17 \\
(41 \%)\end{array}$ & $\begin{array}{l}14 / 22 \\
(64 \%)\end{array}$ & $\begin{array}{c}8 / 22 \\
(36 \%)\end{array}$ & $\begin{array}{c}9 / 18 \\
(50 \%)\end{array}$ & $\begin{array}{c}9 / 18 \\
(50 \%)\end{array}$ \\
\hline
\end{tabular}
macrophage inhibition factor assay using whole sonicates of several mycobacterial antigens

Con $\mathrm{A}=$ concanavalin; $\mathrm{M}=$ mycobacteria $\mathrm{P}=$ paratuberculosis; $\mathrm{K}=$ kansasii; $\mathrm{A}=$ avium; $\mathrm{T}=$ tuberculosis; resp=responders; nonresp $=$ non-responders

According to the Fisher-exact test, there are no statistical differences in the values of the prevalences - that is, p-values $<0.05$.

production - that is, $>20 \%$ inhibition migration, induced by the positive control stimulation with $5 \mu \mathrm{g} / \mathrm{ml}$ of the mitogen con A, reaching inhibition values of $21-80 \%$ (Crohn's disease: mean SE 41 (15); ulcerative colitis: mean SE 46 (14)) (Table). Sixty four per cent of the healthy and controls also had a positive macrophage inhibition factor assay upon con A stimulation (mean
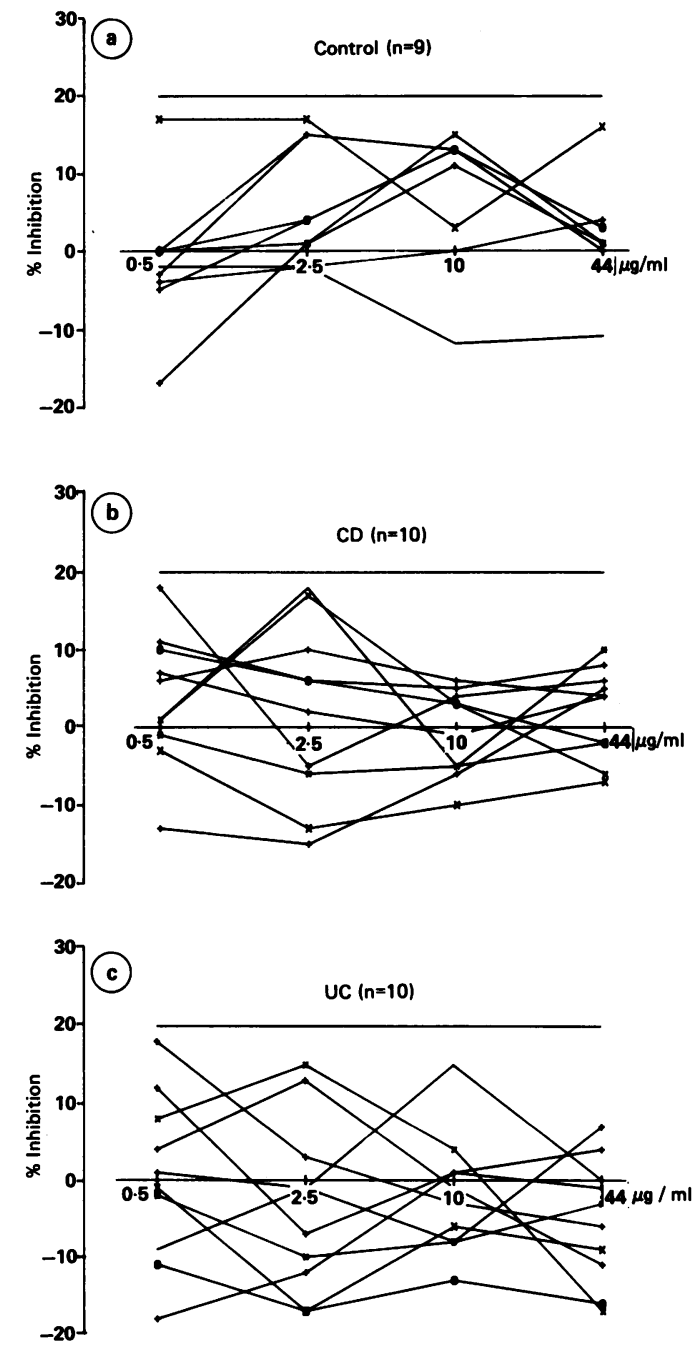

Figure 1: Per cent of migration inhibition using ovalbumin as a negative control antigen in the control $(a)$, Crohn's disease (b), and ulcerative colitis (c) group. Dose response curves were not recorded and the inhibition values never exceeded a $20 \%$ limit (horizontal line). 
Non-responders $(c ; n=7)$
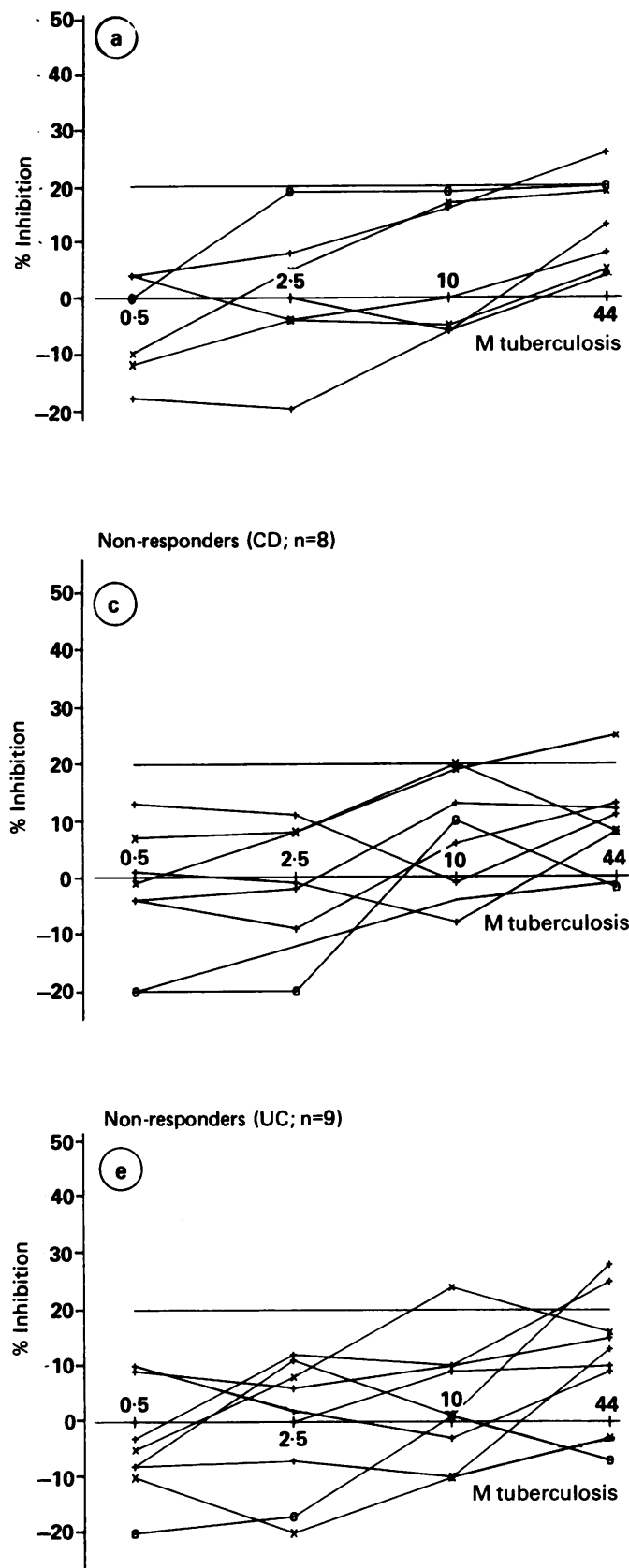
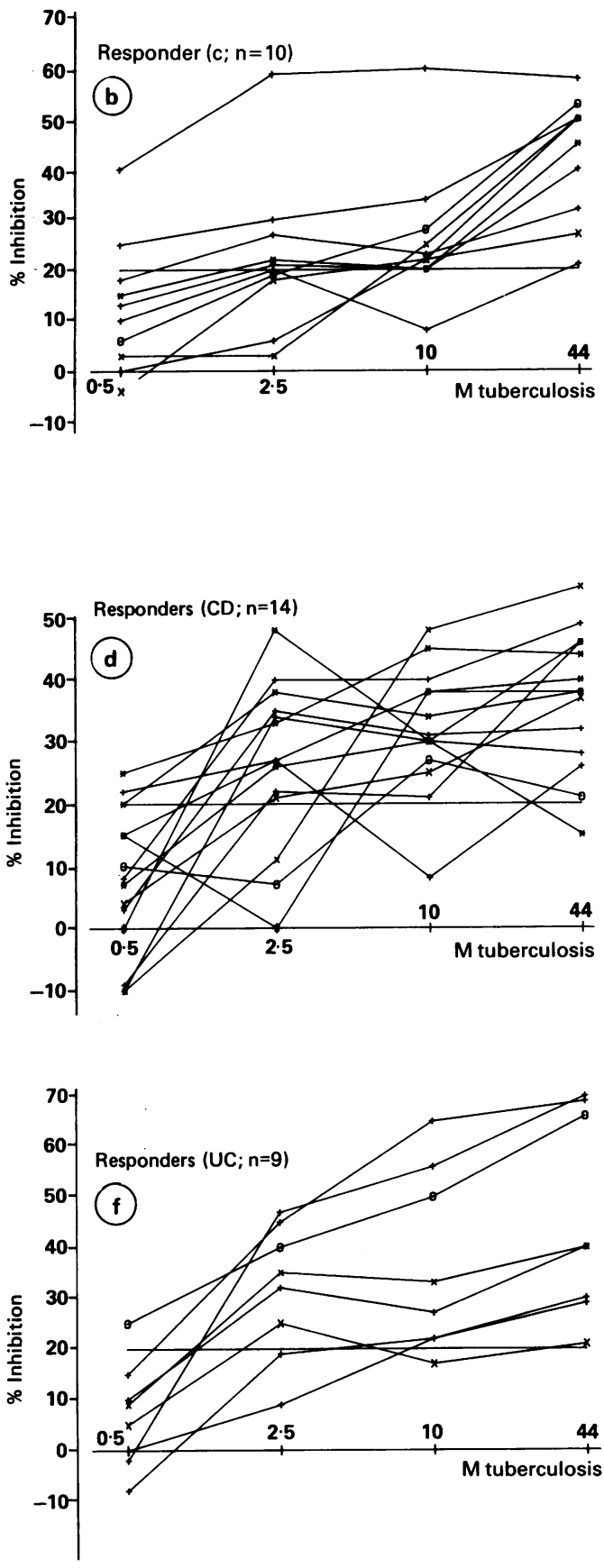

Figure 2: Individual curves illustrating two patterns of responsiveness - that is, non-responders $(a, c, e)$ and responders $(b, d, f)$ in macrophage inhibition factor production in control (c), Crohn's disease $(C D)$, and ulcerative colitis (UC) group using the sonicate of $M$ tuberculosis.

SE 52(13)). According to the Fisher-exact test the differences between the outcomes of the con A macrophage inhibition factor assay in Crohn's disease patients, ulcerative colitis patients and controls (p-values Crohn's disease-ulcerative colitis: $0 \cdot 14$; Crohn's disease-controls: $0 \cdot 21$; ulcerative colitis-controls: 0.92 ) were not statistically significant. This indicates that in general macrophage inhibition factor production of chronic inflammatory bowel disease patients towards a non-specific positive stimulus is intact and similar to that of healthy individuals.

We were able to identify two patterns of responsiveness in patients and healthy controls with regard to the macrophage inhibition factor production towards mycobacterial sonicates: (a) negative responses - that is, dose response curves similar to ovalbumin; (b) positive responses - that is, inhibitions exceeding the $20 \%$ limit in at least two or more concentrations of the sonicates tested and showing a dose response curve.

As an example of the two patterns of responsiveness the individual curves in the control, Crohn's disease, and ulcerative colitis group are shown for the sonicate of $M$ tuberculosis (Fig 2). The other organisms gave similar results.

Patients with such a positive macrophage inhibition factor response to a mycobacterial sonicate are further referred to as 'responders'. The prevalence of 'responders' and 'nonresponders' to the four mycobacterial sonicates is shown in the Table. Significant differences in the 

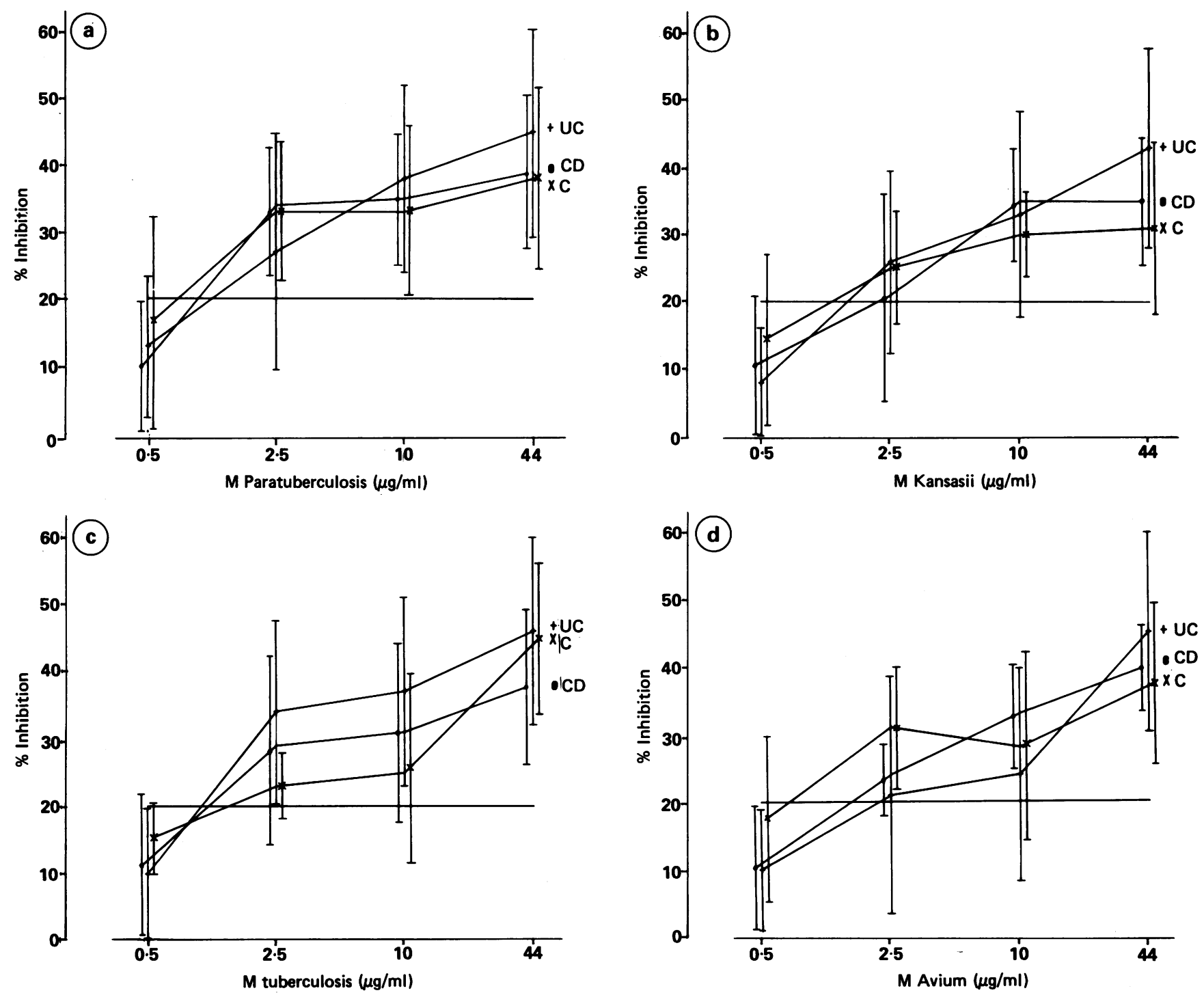

Figure 3: Mean values of migration inhibition with standard error of responders in Crohn's disease, ulcerative colitis, and control group using sonicates of $M$ paratuberulosis $(a), M$ kansasii $(b), M$ tuberculosis $(c)$, and $M$ avium $(d)$ as antigen in four concentrations.

prevalences between the Crohn's disease patients, ulcerative colitis patients, and controls, were not found irrespective of the mycobacterial sonicate used. The high prevalence of responders in all groups indicates that at least some of the sonicated mycobacteria are either commensal or must contain epitopes that occur frequently in our environment.

The actual migration inhibition values of the responders in the Crohn's disease, ulcerative colitis, and control group for each of the dosages of the mycobacterial sonicates used are shown in Figure 3. Clear dose response curves are seen, but statistically significant differences in dose response between Crohn's disease patients, ulcerative colitis patients, or non-chronic inflammatory bowel disease controls are not present.

\section{Discussion}

In this paper $T$-cell mediated immune responsiveness (as measured in macrophage inhibition factor assay) towards four mycobacterial species - that is, a $M$ paratuberculosis strain isolated from Johne's disease, $M$ kansasii strain, a $M$ avium strain, and a $M$ tuberculosis strain was investigated in 35 patients with
Crohn's disease and in 28 patients with ulcerative colitis. Outcomes were compared with those of 25 non-chronic inflammatory bowel disease controls.

Differences in T-cell mediated responsiveness between patients and controls were not detected. If mycobacteria indeed play a role in the pathogenesis of Crohn's disease as suggested by Chiodini et $a l^{5614}$ one could expect a lower (deficient) or higher (immune or allergic) T-cell mediated responsiveness.

Our study has its limitations, however, with regard to the $M$ paratuberculosis strain used. According to a recent DNA sequence analysis of MacFadden $e t a^{28}$ the $M$ paratuberculosis strain NADC 18 shows a very strong structural homology to and is probably even identical to $M$ avium. It is known that in general $M$ paratuberculosis and $M$ avium are closely related to each other $^{29}$ and that the species show a high degree of DNA sequence homology (>90\%). ${ }^{30} \mathrm{M}$ paratuberculosis and $M$ avium are thus antigenically very similar, ${ }^{31}$ and it is not surprising therefore that comparable data were recorded in the macrophage inhibition factor assay using the two strains.

Another limitation of our study is the fact that 
macrophage inhibition factor production from peripheral blood lymphocytes may not reflect the macrophage inhibition factor production of lymphocytes in the diseased organ. As shown in a study by Holoshitz and colleagues ${ }^{32}$ on T-cell mediated immune responsiveness against mycobacteria in patients with rheumatoid arthritis a difference between the reactivity of blood T-lymphocytes and those present in the synovial tissues was found. Therefore mycobacterial specific macrophage inhibition factor production from T-lymphocytes isolated from gut specimens affected by Crohn's disease should also be investigated before making a definite conclusion.

Our findings that mycobacterial specific macrophage inhibition factor production reactivity in chronic inflammatory bowel disease was comparable with that found in healthy and diseased controls, are in contrast with the reports of Burnham et al. ${ }^{7}$ These authors performed delayed type hypersensitivity skin tests with reagents prepared from several mycobacteria, among which was $M$ kansasii, and found a significantly higher percentage of positive cases for $M$ kansasii skin test in patients with Crohn's disease compared with controls. This suggested that $M$ kansasii might be involved in the aetiology of Crohn's disease. These positive skin test data could not be reproduced by others, however ${ }^{213}$; and our results of macrophage inhibition factor production to $M$ kansasii were also negative. An explanation for the differences between Burnham's results and ours might be that we did not use a $M$ kansasii strain which was isolated from a patient with Crohn's disease. It is well known, however, that there is a considerable cross reactivity between the various antigens _of $M$ kansasii and other mycobacteria.

It can also be concluded from our study that a large proportion of the healthy population showed a T-cell response towards the mycobacteria used and the responders rates varied from 59 up to $80 \%$. The reasons for these findings may be the commensal character of some of the mycobacteria ( $M$ avium) and the cross reactivity of various mycobacterial epitopes with other environmental or microbial epitopes. This line of reasoning is in accordance with findings from earlier studies in which certain mycobacteria that is, $M$ kansasii, $M$ avium-intracellulare, $M$ scorfulaceum, $M$ phlei) were easily recovered from food, water, and from sputum, mouth, hands, and intestines of healthy people. ${ }^{174-37}$ Graham et $a l^{17}$ isolated several mycobacterial species not only from the gut of patients with Crohn's disease but also from the gut of noninflammatory bowel disease patients as well as from healthy subjects. Moreover, in a recent report $^{38}$ on DNA-DNA hybridisation, sequences related to mycobacterial DNA ( $M$ paratuberculosis and $M$ avium) were detected in practically all gut specimens. This is supported by the fact that certain mycobacteria - that is, $M$ avium, may be commensals of the gut flora. ${ }^{39}$ Horsburgh and collaborators suggested that this explains why in patients affected by AIDS, disseminated $M$ avium infections are often seen. ${ }^{40}$ It has recently been shown, however, that $M$ avium super infections in AIDS patients are not just the result of invasion by ambient gut or environ- mental strains, but are highly strain specific. ${ }^{41}$

In conclusion, we were unable to detect an abnormal mycobacterial specific $T$-cell mediated immune responsiveness in Crohn's disease or ulcerative colitis patients. These negative results do not provide support for either a defective, allergic, or excessive immune response to any of the four mycobacteriae tested in the pathogenesis of Crohn's disease.

We wish to express our gratitude to Dr J Haagsma for supplying the sonicate of Mycobacterium paratuberulosis, to $\mathrm{Dr} A \mathrm{H} \mathrm{J}$ Kolk for supplying the sonicates of Mycobacterium kansasii, Mycobacterium avium, and Mycobacterium tuberculosis, to Dr C J J Mulder for giving part of the blood samples and to Mrs N W Schipper for statistical analysis of the results. This study has been presented at the Holland Digestive Week, 21-24 June, 1989,
Amsterdam, The Netherlands and has been published as an Amsterdam, The Netherlands
abstract in the congress booklet.

1 Dalziel TK. Chronic intestinal enteritis. $\operatorname{Br} M e d \mathcal{F} 1923$; 2: 1068-70.

2 Parent K, Mitchell P. Cell wall-defective variants of Pseudomonas-like (Group-Va) bacteria in Crohn's disease. Gastroenterology 1978; 75: 368-72.

3 Belsheim MR, Darwish RZ, Watson WC, Schieven B. Bacterial L-form isolation from bowel disease patients. Gastroenterology 1938; 85: 364-9.

4 Pena AS, Weterman IT, Booth CC, Strober W, eds. Recent advances in Crohn's disease. Developments in Gastroenterology advances in Crohn's disease. Developine

5 Chiodini RJ, Van Kruiningen HJ, Thayer WR, Merkal RS, Coutu JA. Possible role of mycobacterium in inflammatory bowel disease. 1. An unclassified mycobacterium species isolated from patients with Crohn's Disease. Dig Dis Sci 1984; 29: 1073-9.

6 Chiodini RJ, Van Kruiningen HJ, Merkal RS, Thayer WR, Coutu JA. Characteristics of an unclassified Mycobacterium species isolated from patients with Crohn's disease. $\mathcal{F}$ Clin Microbiol 1984; 20: 966-71.

7 Burnham WR, Lennard-Jones JE. Mycobacteria as a possible cause of inflammatory bowel disease. Lancet 1978; ii: 693-6.

8 Thayer WR, Coutu JA, Chiodidni RJ, Van Kruiningen HJ, Merkal RS. Possible role of mycobacteria in inflammatory Merkal RS. Possible role of mycobacteria in inflammatory bowel disease. II. Mycobacterial a
disease. Dig Dis Sci 1984; 29: 1080-5.

9 Gitnick G. Is Crohn's disease a Mycobacterial disease after all? [Editorial]. Dig Dis Sci 1984; 29: 1086-8.

10 Hampson SJ, McFadden JJ, Hermon-Taylor J. Mycobacteria and Crohn's disease. Gut 1988; 29: 1017-9.

11 Patterson DSP, Allen W. Chronic mycobacterial enteritis in ruminants as a model for Crohn's disease. Proc $R$ Soc Med 1972; 65: 998-1001.

12 Morgan KL. Veterinary analogy; Johne's and Crohn's: Chronic inflammatory bowel disease of infectious aetiology? Lancet 1987; i: 1017-9.

13 Johne HA, Frothingham L. Ein eigenthuemlicher Fall von Tuberkulose beim Rind. Disch Z Tiermed Pathol 1895; 21: 438-54.

14 Chiodini RJ, Van Kruiningen HJ, Thayer WR, Coutu JA, Merkal RS. Mycobacterial spheroplasts isolated from patients with Crohn's disease [Abstract]. Gastroenterology 1985; 88: 1348 .

15 Golde DW. Aetiology of regional enteritis. Lancet 1968; ii: 1144-5.

16 Yoshimura HH, Merkal RS, Graham DY. DNA hybridization studies of the relationship of Mycobacterium paratuberculosis to other mycobacteria and to an isolate from a Chrohn's disease patient. Abstract of the 85th Annual meeting of the American Society for Microbiology. 1985; March: 103.

17 Graham DY, Markesich DC, Yoshimura HH. Mycobacteria and inflammatory bowel disease: results of culture. Gastroenterology 1987; 2: 436-42.

18 Van de Plassche-Boers EM, Drexhage HA, Kokjé-Kleingeld $M$, Leezenberg HA. Parameters of T-cell mediated immunity to commensal microorganisms in patients with chronic purulent rhinosinusitis: a comparison between chronic purulent rhinosinusitis: a comparison between
delayed type hypersensitivity skin test, lymphocyte transfordelayed type hypersensitivity skin test, lymphocyte transfor-
mation test and macrophage migration inhibition factor assay. Clin Exp Immunol 1986; 66: 516-24.

19 Graybill JJR, Alford RH. Variability of sequential studies of lymphocyte blastogenesis in normal adults. Clin Exp Immunol 1976; 25: 28-35.

20 Thayer WR, Coutu JA, Lopes LA, Chiodini RJ, Van Kruiningen HJ. Prior sensitisation of lymphocytes as a cause of reduced PHA responsiveness in Crohn's disease [Abstract]. Gastroenterology 1987; 92: 1668.

21 Elliott PR, Lennard-Jones, Burnham WR, White S, Stanford $\mathrm{JL}$. Further data on skin testing with mycobacterial antigens in inflammatory bowel disease. Lancet 1980; ii: 483-4.

22 Whitehead R. Major problems in pathology. Vol 3. Mucosal biopsy of the gastrointestinal tract. 3rd ed. Philadelphia: WB Saunders, 1985

23 Merkal RS, McCullough WG, Takayama K. Mycobactins, the state of the art. Bull Inst Pasteur 1981; 79: 251-9.

24 Merkal RS, Kopecky KE, Larsen DVM, Ness RD. Immunologic Mechanism in Bovine Paratuberculosis. Am $\dot{\mathcal{F}}$ Vet Res 1970; 31: 475-85. 
25 Klaster PR, Van Rens MM, Eggelte TA. Immunochemical characterization of Mycobacterium leprae antigens by the SDS-polyacrylamide gel electrophoresis immunoperoxidase technique (SGIP) using patients' sera. Clin Exp Immunol technique (SGIP)

26 Thurman GB, Stull HB, Miller PJ, Stevenson HC, Oldman RK. Utilization of purified human monocytes in the agarose droplet assay for measuring migration inhibitory factors. f Immunol Methods 1983; 65: 41-53.

27 Singh K, Khan A. The usefulness of a monocytoid cell line (U-937) in the macrophage migration inhibition assay. $f$ Clin Hematol Oncol 1982; 12: 29-38.

28 McFadden JJ, Butcher PD, Thompson J, Chiodini R, Hermon-Taylor J. The use of DNA probes identifying restriction-fragment-length-polymorfisms to examine the Mycobacterium avium complex. Mol Microbiol 1987; 3: 283-91.

29 McFadden JJ, Butcher PD, Chiodini R, Hermon-Taylor J. Crohn's disease-isolated Mycobacteria are identical to Mycobacterium paratuberculosis, as determined by DNA probes that distinguish between mycobacterial species. probes that distinguish between

30 Baess I. Desoxyribonucleic acid relatedness among species of slow-growing mycobacteria. Acta Pathol Microbiol Scand [B] 1979; 87: 221-6.

31 McIntyre GM, Stanford JL. Immunodiffusion analysis shows that Mycobacterium paratuberculosis and other mycobactine-dependent mycobacteria are variants of Mycobacterium avium. F Appl Bacteriol 1986; 61: 295-8.

32 Holoshitz J, Drucker I, Yaretzky A, et al. T lymphocytes of rheumatoid arthritis patients show augmented reactivity to a 1986; ii: 305-9.

33 Whorwell PJ, Beeken WL, Davidson IW, Wright R. Search by immunofluorescence for antigens of rotavirus, pseudomonas maltophilia, and mycobacterium Kansasii in Crohn's monas maltophilia, and myco

34 Mills CC. Occurrence of Mycobacterium other than Mycobacterium tuberculosis in the oral cavity and in sputum Appl Microbiol 1972; 24: 307-10.

35 Edwards LB, Palmer CE. Isolation of 'atypical' mycobacteria from healthy persons. Am Rev Respir Dis 1959; 80: 747-9.

36 Kazda JF. The principles of the ecology of mycobacteria. In Radledge C, Stanford J, eds. The biology of mycobacteria. Vo 2. London: Academic, 1983: 323-41

37 Shield MJ. The importance of immunologically effective contact with environmental mycobacteria. In: Radledge $C$ Stanford J, eds. The biology of mycobacteria. Vol 2. London: Academic, 1983: 343-415.

38 Yoshimura HH, Graham DY, Estes Mk, Merkal RS. Investigation of association of mycobacteria with inflammatory bowel disease by nucleic acid hybridization. 7 Clin Microbiol 1987; 25: 45-51.

39 Portaels F, Larsson L, Smeets P. Isolation of mycobacteria Portaels F, Larsson L, Smeets P. Isolation of mycobacteria
from healthy persons' stools. Int f Leprosy 1988; 56: 468-71. 40 Horsburgh CR, Mason UG, Farhi DC, Iseman MD. DissemiHorsburgh CR, Mason UG, Farhi DC, Iseman MD. Dissemi-
nated infection with Mycobacterium avium-intracellular.

41 Hampson SJ, Portaels F, Thompson J, et al. DNA probes demonstrate a single highly conserved strain of mycobacterium avium infecting AIDS patients. Lancet 1989; i: 65-8. 